\title{
Multiple actions of lysophosphatidic acid on fibroblasts revealed by transcriptional profiling Catelijne Stortelers ${ }^{1,3}$, Ron Kerkhoven ${ }^{2}$ and Wouter H Moolenaar*1
}

\begin{abstract}
Address: ${ }^{1}$ Division of Cellular Biochemistry and Centre for Biomedical Genetics, The Netherlands Cancer Institute, Plesmanlaan 121,1066 CX Amsterdam, The Netherlands, ${ }^{2}$ Central Microarray Facility, The Netherlands Cancer Institute, Plesmanlaan 121, 1066 CX Amsterdam, The Netherlands and ${ }^{3}$ Ablynx, Technologiepark 4, 9052 Ghent/Zwijnaarde, Belgium

Email: Catelijne Stortelers - c.stortelers@gmail.com; Ron Kerkhoven - r.kerkhoven@nki.nl; Wouter H Moolenaar* - w.moolenaar@nki.nl

* Corresponding author
\end{abstract}

Published: 14 August 2008

BMC Genomics 2008, 9:387 doi:10.1/86/147|-2164-9-387
Received: 25 April 2008

Accepted: 14 August 2008

This article is available from: http://www.biomedcentral.com/I47I-2/64/9/387

(C) 2008 Stortelers et al; licensee BioMed Central Ltd.

This is an Open Access article distributed under the terms of the Creative Commons Attribution License (http://creativecommons.org/licenses/by/2.0), which permits unrestricted use, distribution, and reproduction in any medium, provided the original work is properly cited.

\begin{abstract}
Background: Lysophosphatidic acid (LPA) is a lipid mediator that acts through specific G proteincoupled receptors to stimulate the proliferation, migration and survival of many cell types. LPA signaling has been implicated in development, wound healing and cancer. While LPA signaling pathways have been studied extensively, it remains unknown how LPA affects global gene expression in its target cells.

Results: We have examined the temporal program of global gene expression in quiescent mouse embryonic fibroblasts stimulated with LPA using $32 \mathrm{k}$ oligonucleotide microarrays. In addition to genes involved in growth stimulation and cytoskeletal reorganization, LPA induced many genes that encode secreted factors, including chemokines, growth factors, cytokines, pro-angiogenic and profibrotic factors, components of the plasminogen activator system and metalloproteases. Strikingly, epidermal growth factor induced a broadly overlapping expression pattern, but some $7 \%$ of the genes (105 out of 1508 transcripts) showed differential regulation by LPA. The subset of LPAspecific genes was enriched for those associated with cytoskeletal remodeling, in keeping with LPA's ability to regulate cell shape and motility.

Conclusion: This study highlights the importance of LPA in programming fibroblasts not only to proliferate and migrate but also to produce many paracrine mediators of tissue remodeling, angiogenesis, inflammation and tumor progression. Furthermore, our results show that $\mathrm{G}$ proteincoupled receptors and receptor tyrosine kinases can signal independently to regulate broadly overlapping sets of genes in the same cell type.
\end{abstract}

\section{Background}

Lysophosphatidic acid (LPA; monoacyl-glycerol-3phoshate) is a lipid mediator that stimulates the proliferation, migration and survival of many cell types [1]. LPA acts through at least five distinct $G$ protein-coupled receptors (GPCRs), termed $\mathrm{LPA}_{1-5}$, which show overlapping signaling properties and tissue distribution $[2,3]$. LPA sig- naling has been implicated in a great variety of biological processes, ranging from embryonic development to wound healing and tumor progression [1-5]. This multitude of activities is consistent with the broad distribution of LPA receptors and their coupling to multiple G proteins. LPA is produced from more complex lysophospholipids by a secreted lysophospholipase $\mathrm{D}$ known as 
autotaxin (ATX), originally identified as an 'autocrine motility factor' for tumor cells (for review see ref. [3]). ATX is essential for vascular development $[6,7]$ and in addition promotes tumor aggressiveness and angiogenesis [8]. This strongly suggests that LPA is a key pro-angiogenic factor during development and a signifcant effector of cancer progression in the stroma-tumor microenviroment.

Although LPA-induced signaling pathways and cellular responses have been extensively analyzed over the years [1], it remains unknown how LPA affects global gene expression in its target cells. Gene expression analysis may uncover previously unknown activities of LPA, lead to a better understanding of GPCR signaling in general, and help to predict the behavior of cells in an LPA-enriched environment.

In this report, we analyze the global transcriptional response to LPA in mouse embryo fibroblasts (MEFs). Fibroblasts are abundant mesenchymal cells in the stroma of many tissues and organs where they regulate epithelialmesenchymal interactions during development, tissue regeneration and tumor progression $[9,10]$. LPA has long been known to stimulate the proliferation and migration of fibroblasts $[1,11]$, while excessive LPA signaling in these cells can lead to fibrosis [12]. The present study identifies many novel LPA-regulated genes and shows especially that LPA commits fibroblasts, at the transcriptional level, to create a microenvironment that supports tissue remodeling, leukocyte recruitment, angiogenesis and tumor progression. Since fibroblasts are also responsive to epidermal growth factor (EGF), acting on its cognate receptor tyrosine kinase, we examined in addition to what extent the LPA- and EGF-induced expression patterns overlap.

\section{Results and Discussion Characterization of MEFs}

We examined the mitogenic response and LPA receptor expression profile of immortalized mouse embryonic fibroblasts (MEFs). Stimulation of serum-deprived, nearly confluent MEFs with saturating doses of LPA $(5 \mu \mathrm{M})$ resulted in a significant increase in DNA synthesis to about $40 \%$ the level induced by $10 \%$ serum. EGF (50 ng/ $\mathrm{ml}$ ) was somewhat less efficacious than LPA in stimulating DNA synthesis (Figure 1A). LPA signals via at least five distinct GPCRs (termed $\mathrm{LPA}_{1-5}$ ) that couple to multiple $\mathrm{G}$ proteins, including $\mathrm{G}_{\mathrm{i} / \mathrm{o}^{\prime}}, \mathrm{G}_{\mathrm{q} / 11}$ and $\mathrm{G}_{12 / 13}$. Quantitative PCR analysis showed that our MEFs co-expressed $\mathrm{LPA}_{1}$, $\mathrm{LPA}_{2}$ and $\mathrm{LPA}_{4}$, with $\mathrm{LPA}_{1}$ and $\mathrm{LPA}_{4}$ being the predominant transcripts (Figure $1 \mathrm{~B}$ ). Since MEFs do not express ATX (encoded by Enpp2; data not shown), autocrine LPA signaling is not operative in our cell system.

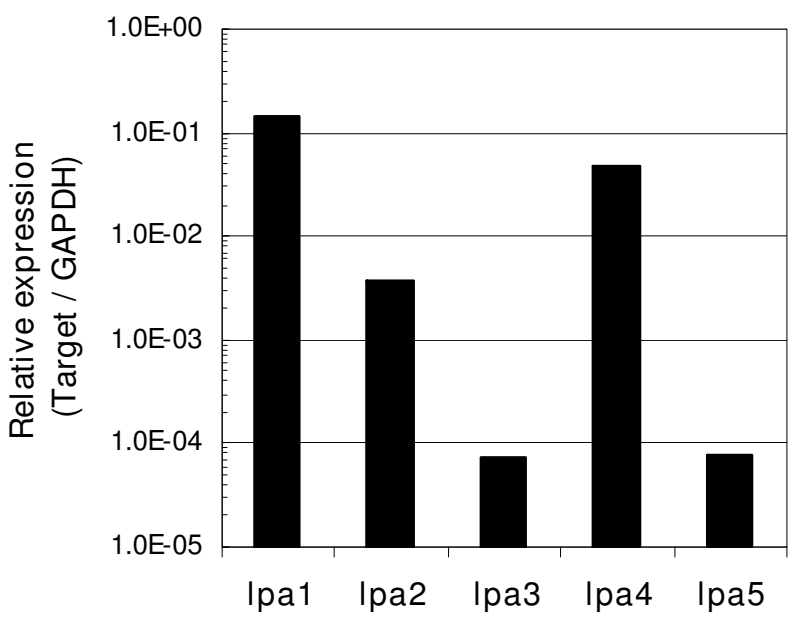

Figure I

Characterization of MEFs. (A) Mitogenic responsiveness of MEFs as measured by $\left[{ }^{3} \mathrm{H}\right]$ thymidine incorporation. Serumdeprived cells ("control") were treated with fetal calf serum (FCS; I0\%), LPA (I0 $\mu \mathrm{M})$ or EGF (25 ng/ml). The response to FCS was set at $100 \%$. Bars represent means $\pm S D(N=3)$. (B) LPA receptor expression in MEFs. Expression levels were determined by qPCR using the GAPDH gene for normalization. Expression levels of $\mathrm{LPA}_{3}$ and $\mathrm{LPA}_{5}$ are negligible. 


\section{The global transcriptional response to LPA}

We examined the temporal program of gene expression in serum-starved MEFs treated with LPA ( $5 \mu \mathrm{M}$, i.e. about the normal concentration in serum [13]). Total RNA was isolated at different time points after LPA stimulation (0-24 hrs). Global transcription profiles were determined using oligonucleotide microarrays containing 31,770 mouse transcripts. Amplified RNA of the treated samples was matched with the untreated control and hybridized in duplicate with reversal of the Cy3 and Cy5 dyes; the normalized Cy5/Cy3 ratios were combined and used for further analysis. We selected genes that were significantly regulated $(\mathrm{p}<0.01)$ at two or more consecutive time points or in replicate measurements, which yielded 1508 LPA-regulated genes (see additional file 1: complete dataset). The entire dataset has been deposited in the EBI/ ArrayExpress database (see Methods). We restricted our data set to genes that were induced by $>1$.7-fold at two or more time points and grouped them according to the temporal profile of gene induction using K-means clustering. This resulted in ten clusters, each containing genes that show similarly shaped waves of transcription (Figure 2). Seven clusters contained genes that were upregulated by LPA (424 transcripts), whereas three other clusters mainly comprised the down-regulated genes (209 transcripts) (Figure 2; for details see additional files 2 and 3). The genes that were most strongly regulated at different time points are listed in additional file 4 (Table 1: upregulated genes; Table 2: downregulated genes). The microarray results were validated by examining the expression of 22 representative genes from different clusters using realtime PCR (Figure 3). The -fold inductions of expression generally were higher in the GPCR assays than in the corresponding microarray experiments, reflecting the different sensitivities of both methods (see additional file 5: correlation plot of all data points). Gene ontology analysis revealed that LPA regulated the expression of genes in multiple functional categories that mostly corresponded to the different gene clusters (see additional file 6).

\section{Regulation of genes associated with growth regulation and cytoskeletal reorganization \\ Upregulated genes}

The immediate transcriptional response to LPA was characterized by $>100$ upregulated immediate-early genes (mRNA levels peaking at $0.5-1 \mathrm{hr}$ ) (Figure 2; see additional files 2 and 2/Table 1 ). This gene set contained various transcription factors associated with growth stimulation and cell cycle progression, notably genes encoding the AP-1 complex (Fos, Fra1/FosL1, Jun, Atf3) and other growth regulatory genes (Egr1, Egr2, KlfG, Myc). Strong upregulation was also observed for Ptgs2, a highly inducible gene that encodes cyclooxygenase-2 (Cox-2) and has important roles in normal tissue homeostasis and inflammation. Upregulation of some of these immediateearly genes, including Egr1, Jun, M $\gamma c$ and Ptgs2, has earlier
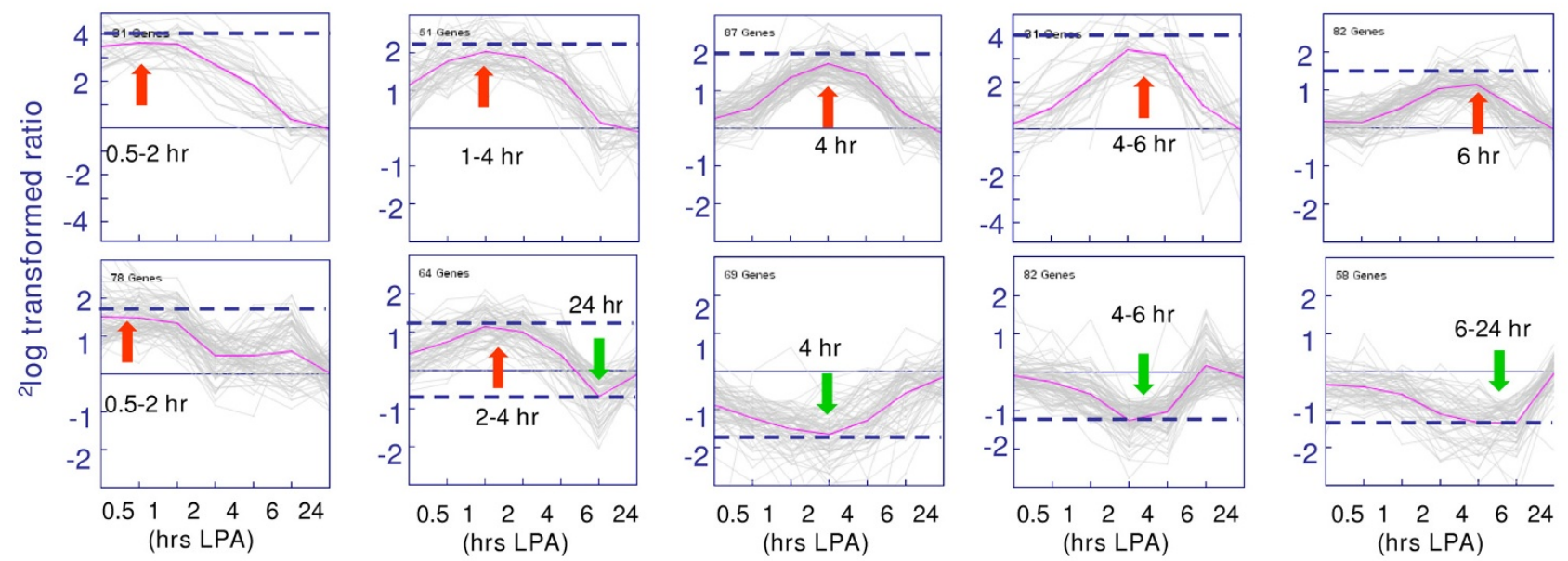

\section{Figure 2}

Global transcriptional response of MEFs to LPA. Gene expression patterns induced by LPA (5 $\mu$ M) clustered into I0 different classes ( $\mathrm{K}$-means clustering analysis; $\mathrm{N}=10$ ). Clusters were generated based on the time point of maximal induction. Data indicate 2 log ratios of transcripts with $p \leq 0.001$ in at least two consecutive time points (resulting in 633 selected transcripts). Each column represents one time point of LPA treatment; the last column shows the expression in non-synchronized MEFs. The time point or period of maximal induction (red) or reduction (green) is indicated in each cluster by an arrow and the respective hour. Solid lines (pink) indicate the median temporal pattern of expression; dotted lines indicate the median level for each cluster. See additional files 2 and 3 for details of the individual clusters. 

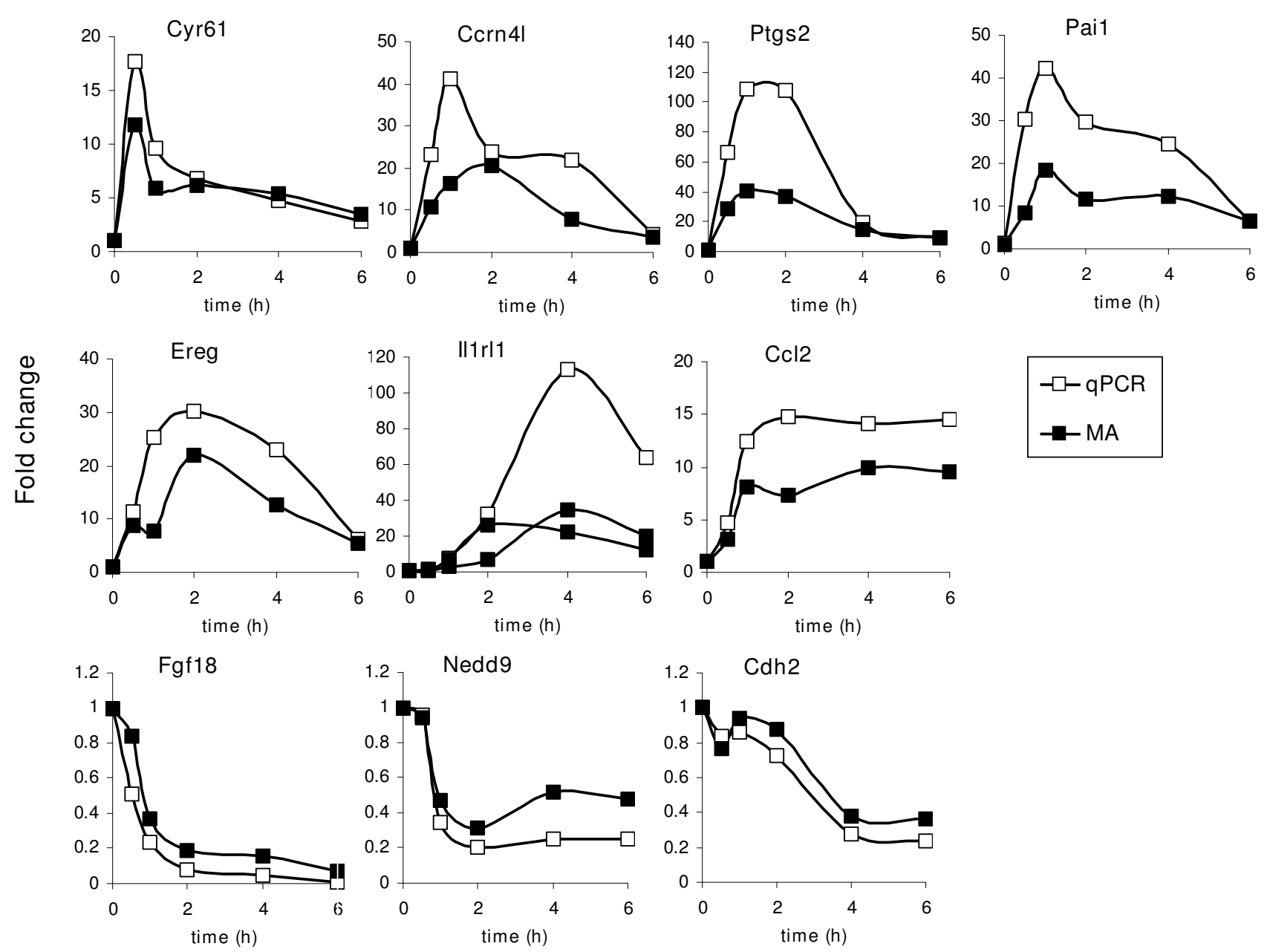

Figure 3

Validation of microarray data. Comparison of the relative expression levels of genes selected from different clusters, as determined by microarray (closed symbols) and qPCR (open symbols). qPCR data were normalized to HPRT mRNA concentration and plotted relative to the level at time zero. Data are presented as means \pm SD of duplicate experiments. Note that the qPCR assays generally yielded higher mRNA values than the microarray analysis. See also the correlation plot in additional file 6.

been found in LPA-treated MEFs and ovarian carcinoma cells $[14,15]$. LPA also induced the expression of genes encoding growth-regulatory protein kinases, including Sgk1, Dyrk3, Nuak2 and Map2k3 (Mek3). In addition to these 'forward-driving' genes, the early gene clusters contained various 'feedback regulators' known to turn off gene expression and/or attenuate prolonged signaling (see additional file 4: Table 1). Co-expression of both negative and positive regulators may be critical for the precise control of cell cycle progression. Among the feedback regulators induced by LPA were transcriptional repressors (Ztbtb16, Lfrd1/Tis7, Pawr), genes that promote the degradation of inducible mRNAs (Zfp36, Nocturnin/Ccrnl2) and a number of dual-specificity phosphatase (DUSP) genes, notably Dusp1, Dusp5, Dusp6, and Dusp10, whose products attenuate the activity of MAP kinases [16]. It is further of note that LPA induced a very robust upregulation of Mig-6 also known as Errfil (ErbB receptor feedback inhibitor 1 ; 60-fold induction after $2 \mathrm{~h}$ ). MIG-6 is a scaffold protein that interacts with the EGF receptor to inhibit its catalytic activity and all downstream signaling events $[17,18]$. By upregulating Mig-6, LPA may keep fibroblasts poised to prevent uncontrolled EGF receptor activation.

In addition to the above growth-regulatory genes, prominent upregulation was observed for genes whose products regulate the cytoskeleton, including various actin isoforms, vinculin and integrin alpha-subunits (Itga5 and 
Itga6), consistent with LPA's function as a regulator of cell shape and motility (see additional file 4 : Table 1 ).

\section{Downregulated genes}

Strongest downregulation of gene expression was mostly observed at 4-6 hrs after LPA stimulation, i.e. coincident with the mid-G1 phase of the cell cycle (Figure 2; see additional file 3 ). The most strongly down-regulated genes are listed in additional file 4 (Table 2); it comprises the transcription factor Sox4, recently identified as a mediator of metastasis [19], the transcriptional repressor Slug (Snai2), an inducer of the mesenchymal phenotype and a marker of malignancy [20], as well as genes that promote growth arrest. The latter set included the cell cycle inhibitors Cong2 (encoding cyclin G2) and Cdkn1b (p27Kip), and the 'growth arrest-specific' genes Gas1-3 and Con5. The latter gene encodes a growth inhibitory matrix protein (CCN5) whose reduced expression promotes mesenchymal cell motility [21]. Other strongly downregulated genes were Nedd9/Hef1 and Cdh2. The Nedd9 scaffold is a downstream effector of focal adhesion kinase that may transduce integrin "inside-out" signaling to regulate cell-matrix adhesion and invasion [22,23], while Cdh 2 encodes Ncadherin, a key regulator of intercellular adhesion strength in fibroblasts [24]. Through the coincident loss of $\mathrm{N}$-cadherin, Nedd9 and CCN5, together with the upregulation of secreted metalloproteases (see below), LPA-stimulated fibroblasts may reduce their adhesive contacts and acquire a more motile and invasive phenotype.

\section{Induction of genes that encode secreted factors}

Aside from genes associated with cell proliferation and motility, the immediate-early and early clusters contained many genes that encode paracrine factors such as chemokines, cytokines, mitogens and pro-angiogenic factors that are involved in inflammation, tissue remodeling and wound healing. Previous studies have shown that LPA induces the expression of the chemokine CXCL1/Groalpha and the cytokines IL- 6 and IL- 8 in ovarian cancer cells $[25,26]$. Figure 4 shows a heat map for 34 selected genes that encode secreted factors, with the most strongly induced genes at the top of the map. These include genes encoding CXCL1/Gro-alpha, IL-6, the EGF family members HB-EGF, epiregulin and amphiregulin, PDGF-A, CSF1 , VEGF-A and the 'pro-fibrotic' and vasoactive ligand endothelin-1 (End1). LPA also triggered robust upregulation of Ccn1/Cyr61 (peaking at $0.5 \mathrm{hr}$ ) and Ccn2/Ctgf (connective-tissue growth factor; peaking at $2 \mathrm{hrs).} \mathrm{The}$ $C c n$ genes encode matrix proteins that control cell attachment and migration, but also are important players in the pathogenesis of fibrosis [27].

Components of the urokinase-type plasminogen activator (uPA) system, notably PlauR (uPAR; peaking at $2 \mathrm{hrs)} \mathrm{and}$ the two major inhibitors of this system, plasminogen acti- vator inhibitor-1 (PAI-1; peaking at 2-4 hrs) and PAI-2 (peaking at 4-6 hrs) were also strongly upregulated by LPA. Through its action on extracellular matrix and cellsurface proteins, the uPA system modulates cell migration and cell-matrix interactions and thereby plays a key role in wound healing, angiogenesis and tumor progression.

Genes encoding additional extracellular mediators and surface-exposed proteins were induced in a second wave of transcription with expression peaking at 4-6 hr after LPA stimulation (Figure 2; see additional files 3 and 4/ Table 1). These included the chemokines CCL-2, CCL-7 and $\mathrm{Cx} 3 \mathrm{Cl} 1$, the matrix metalloproteinases Adam 19 and MMP3, and the transmembrane glycoprotein CD44, which plays a key role in cell-cell interactions. A very strongly upregulated gene was ILl1rl1, which encodes an IL-1 receptor family member (murine ST2; 40-fold induction at $4 \mathrm{hrs}$ ). The secreted form of ST2 inhibits the production of cytokines in inflammatory cells [28]. Thus, ST2 upregulation in LPA-stimulated fibroblasts may serve to temper inflammatory responses. Consistent with our data, ST2 was recently identified as major LPA target gene in osteoblastic cells, where it is thought to play an antiinflammatory role during bone healing [29]. Strong upregulation was also observed for tissue factor (coagulation factor III, encoded by F3), a cell-surface glycoprotein that initiates the clotting cascade and has additional roles in cell migration and angiogenesis [30]. Late upregulation (peak expression at $\sim 6$ hrs: see additional file 3 ) was observed for Lgals3 and Timp1. Lgals3 encodes galactin-3, a mediator of inflammation, while secreted Timp-1 has a role in wound healing and the creation of a prometastatic niche.

In conclusion, LPA-stimulated fibroblasts are transcriptionally committed to produce numerous factors known to act on nearby epithelial cells, leukocytes and endothelial cells. LPA stimulation thus enables fibroblasts to promote tissue remodeling, inflammation, angiogenesis, wound healing and, in a tumor context, cancer progression. A schematic representation of the LPA-induced gene expression program over time is shown in additional file 7.

\section{LPA dose dependence}

The early cellular responses to LPA, such as cytoskeletal reorganization and migration, usually show their maximal induction in the submicromolar concentration range, while cell cycle progression requires 1-5 $\mu \mathrm{M}$ doses. We determined the dose-efficacy of LPA on gene transcription using three different concentrations $(0.3,1.0$ and $5 \mu \mathrm{M})$ and analyzed expression profiles over time ( $0-4 \mathrm{hrs})$. The regulation of many LPA target genes was preserved at the lowest LPA dose tested $(0.3 \mu \mathrm{M})$. About $65 \%$ of all target genes showed significant regulation by LPA at all three 

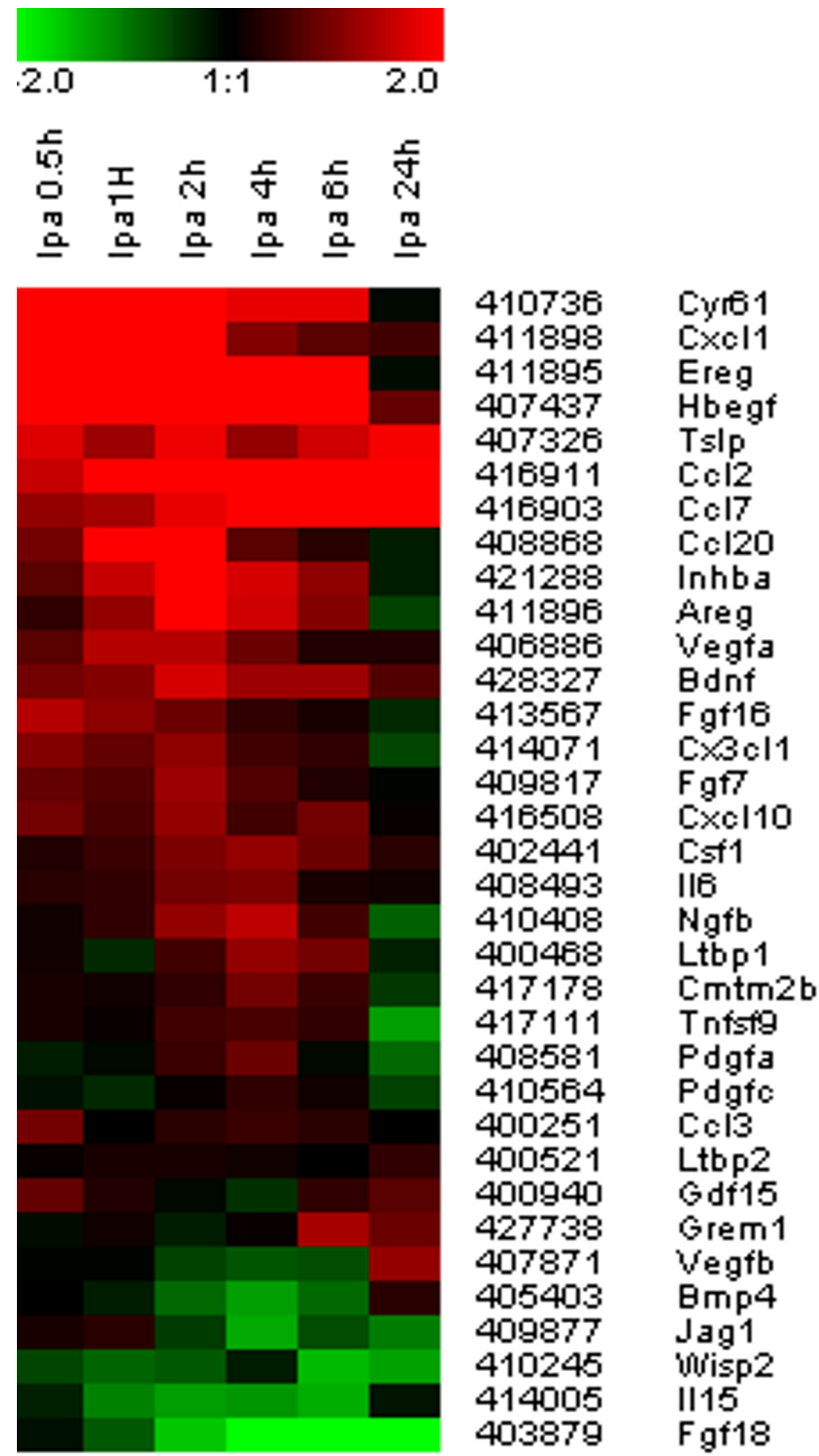

Figure 4

Temporal expression pattern of LPA-regulated genes that encode secreted factors. The heat map shows expression profiles of 34 selected genes as indicated. See also additional file 4 (Table I). 
LPA doses (P-values $<0.01$; although in many cases the ratios decreased below the threshold of 1.7 -fold induction). Increasing the LPA concentration caused increasingly stronger gene expression, often with more prolonged kinetics, as visualized by heat map (Figure 5) and quantitated for selected genes by qPCR (Figure 6). It is of note that many of the genes encoding secreted factors (Il1rl1, Pai2, Ccl2, Ccl7, Cx3Cl1, Hbegf, Vegf) reached their maximal expression already at $0.3 \mu \mathrm{M}$ LPA. "Ingenuity" pathway analysis indicated that the functional categories modulated by LPA were preserved at all three concentrations, with the notable exception that lowering the LPA

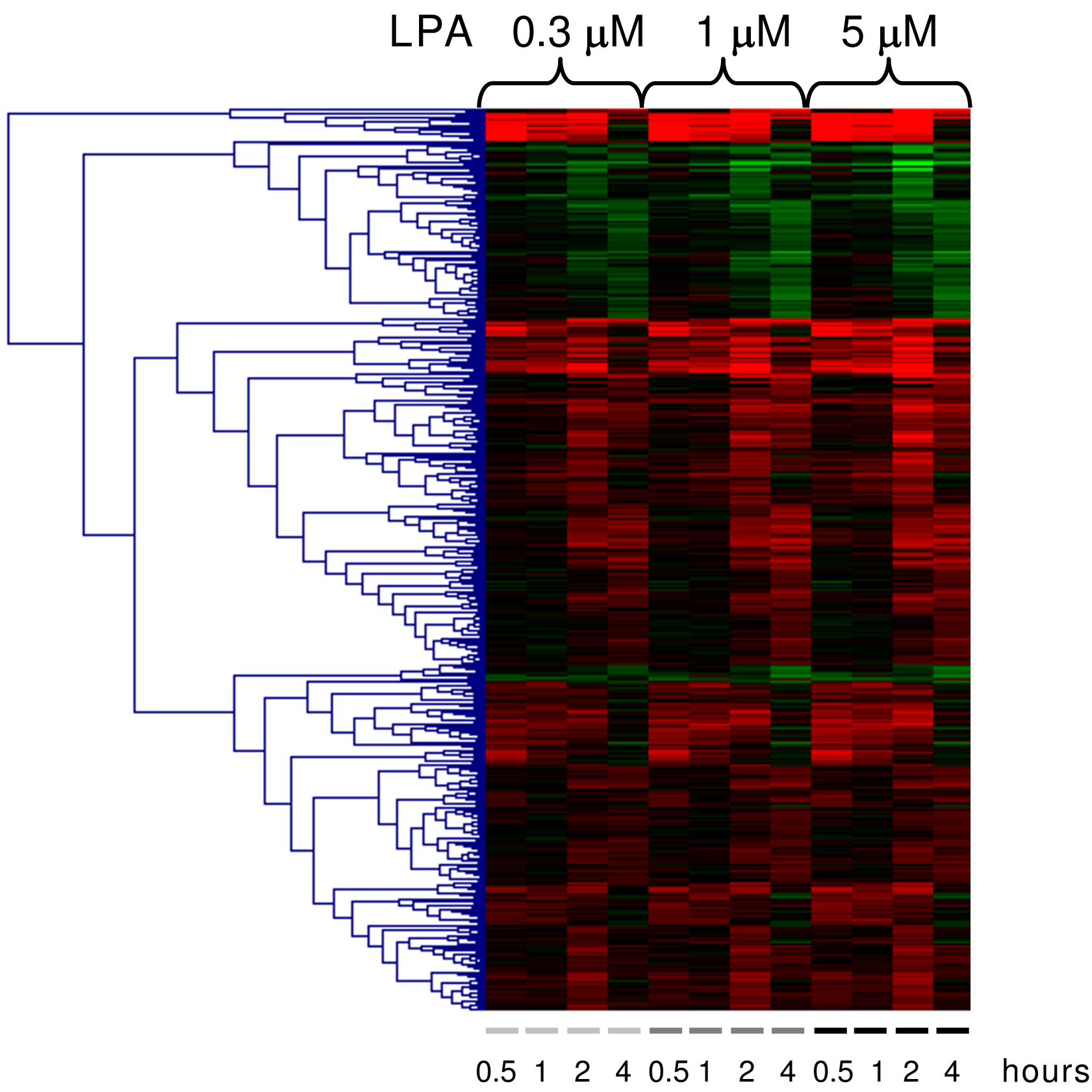

Figure 5

LPA dose dependence. The global transcriptional response of quiescent MEFs to different LPA concentrations ( 0.3 , I.0 and $5.0 \mu \mathrm{M})$ at the indicated time points $(0.5-4 \mathrm{hrs})$. For each time point, transcripts with $p<0.0 \mathrm{l}$ in 3 out of 4 measurements were selected; the resulting 915 genes were subjected to hierarchical clustering analysis. 


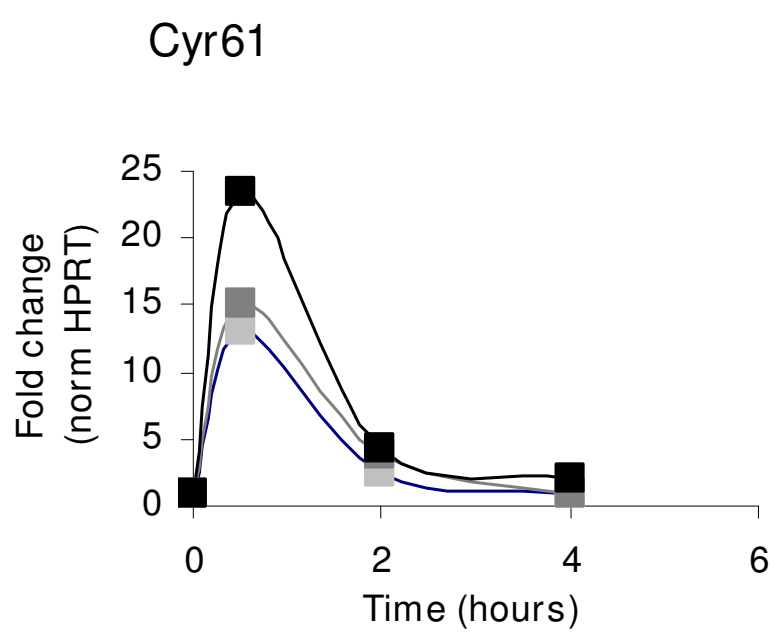

Pai1

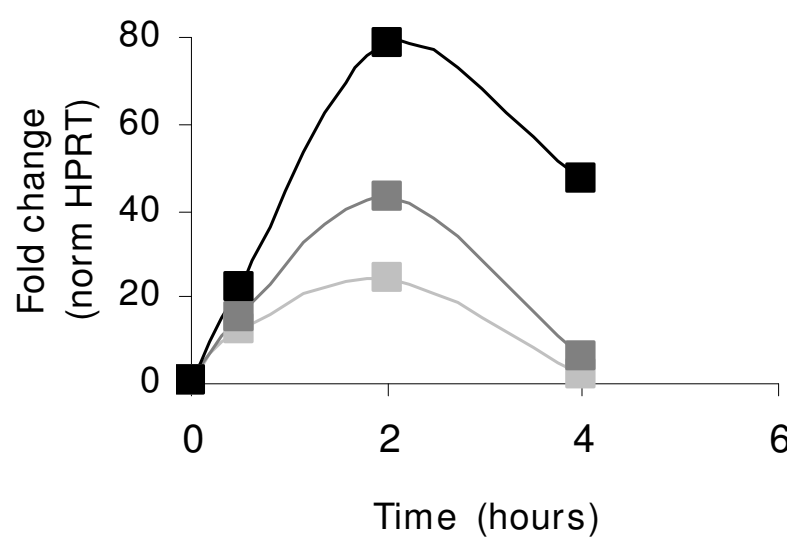

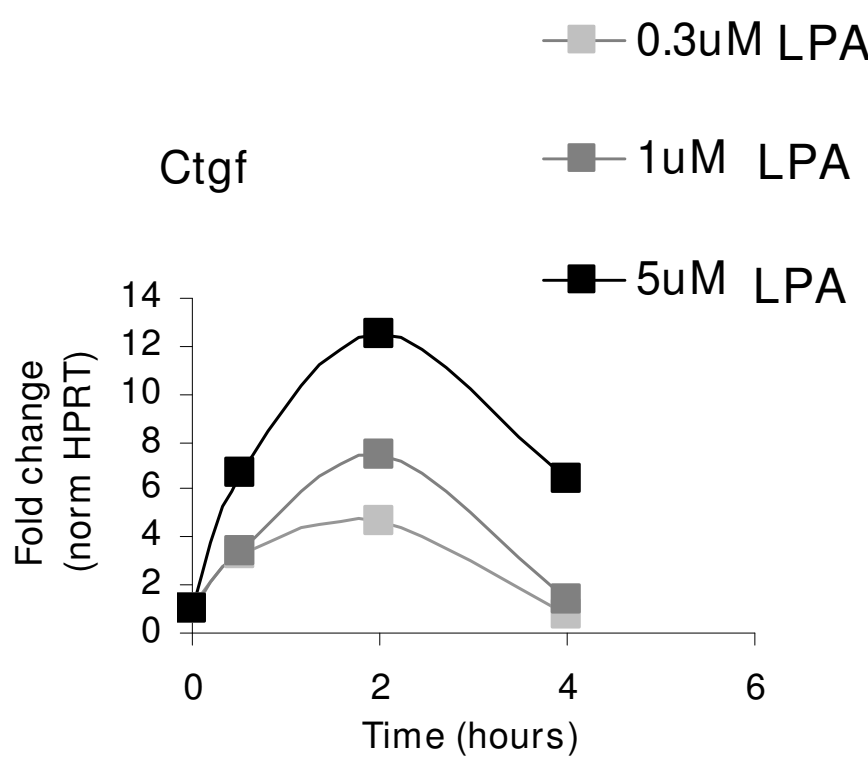

Cox2

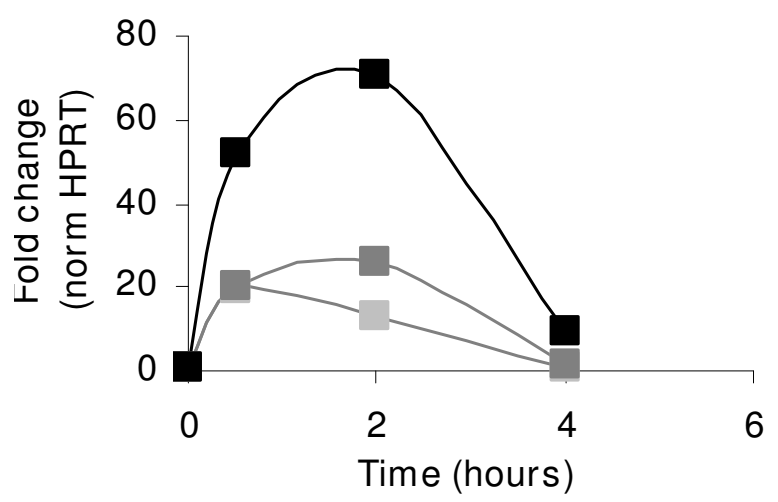

Figure 6

Temporal expression of selected genes at different LPA concentrations validated by qPCR. qPCR data were normalized to HPRT mRNA concentration and plotted relative to the level at time zero. Data are presented as means \pm SD of duplicate experiments.

dose to $0.3 \mu \mathrm{M}$ led to a relative enrichment of genes associated with "cell movement" (Figure 7). This result is consistent with LPA's propensity to act as a motility factor and chemo-attractant rather than a growth factor in the lower concentration range.

Expression profiles of LPA and EGF show broad overlap, but at least 100 genes are differentially regulated

Fibroblasts have long been used as a model to study peptide growth factor signaling. When stimulated by distinct peptide growth factors (EGF, FGF, PDGF), fibroblasts show a strongly conserved gene-expression signature [31]. This is not too surprising since the cognate receptor tyrosine kinases (RTKs) all use the same signaling principle. To our knowledge, however, it is unknown to what extent the transcriptional response to GPCR stimulation bears comparison with that to RTK stimulation in the same cell type. We therefore compared the temporal gene expression programs of LPA and EGF in MEFs at five different time points $(0.5-6 \mathrm{hrs})$. We found that EGF $(20 \mathrm{ng} / \mathrm{ml})$ induced many of the same genes as LPA $(5 \mu \mathrm{M})$, although LPA stimulation often led to a higher level of induction 


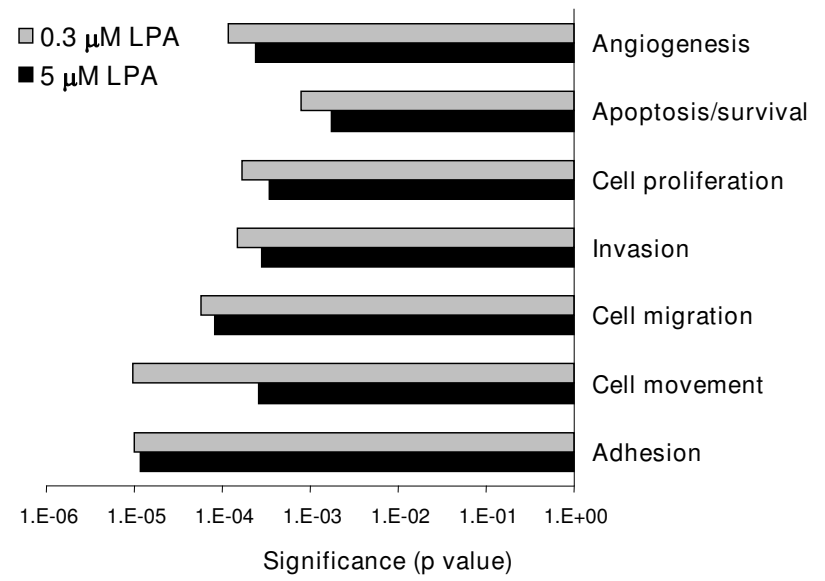

Figure 7

Ingenuity pathway analysis of gene expression at two different LPA concentrations. Note relative enrichment of 'cell movement' genes at the lower LPA concentration.

and/or more prolonged kinetics (Figure 8A,B). For example, LPA caused a much more prolonged upregulation of the immediate early genes Fos, Dusp1 and Cxcl1 than did EGF (Figure 8B; see additional file 8: cluster 1). LPA was also more efficacious in inducing genes that encode paracrine factors (Ccl2, Ereg, Il1RL1, Ctgf, Vegfa) and components of the plasminogen activator system (Plaur, Pai-1) (Figure 8B). Quantitative PCR analysis confirmed the differential regulation of selected genes by LPA and EGF (Figure 9). A complete list of the differentially regulated genes is shown in additional file 9. To what extent these quantitative differences reflect different expression levels of the respective receptors is currently unknown.

Despite this large overlap of the LPA and EGF expression profiles, approx. $7 \%$ of the genes (105 out of 1508 transcripts) was differentially regulated by LPA (Figure 8; see additional files 8 and 9). Immediate-early genes that were upregulated by LPA, but not EGF, include Edn1 (endothelin-1), Fgf16, Nfkbia (NF-kappaB inhibitor alpha) and several protein kinase genes (Bmp2k, Plk2, Tesk2, Pim1), as shown in additional file 8 (cluster 3). Interestingly, LPA also induced the expression of a newly identified GPCR for LPA, termed P2Y5 (encoded by P2ry5 [32]), which adds an element of feedback to the fibroblast response to LPA (see additional file 8: cluster 3). At 2-4 hrs, more LPA-specific transcripts could be identified (Figure 8B; see additional files 8 and 9). Gene ontology analysis revealed that the LPA-specific gene set was enriched for genes associated with cytoskeletal organization and integrin signaling, notably those encoding various actin isoforms (Actb, Acta1, Actg2), palladin (Palld), vinculin (Vcl), an Arp2/3 subunit (Arpc5), calponins (Cnn1, Cnn3), a Rho GTPase (Rhoj), Rho-kinase (Rock2), myosin X (Myo10) and an integrin subunit (Itga5) (see additional file 9). Specific upregulation of cytoskeleton-associated genes is in line with LPA's role as an efficacious regulator of cell shape and motility.

It has long been proposed that GPCR ligands such as LPA signal through 'transactivation' of the EGF receptor $[33,34]$. According to this model, GPCR agonists rapidly activate the EGF receptor to exploit the tyrosine-posphorylated receptor as a signaling intermediate. However, blocking EGF receptor activity by the selective EGF receptor kinase inhibitor AG1478 (250 nM) had no effect on LPA-induced MAP kinase activation, Ccl2 expression and DNA synthesis, while the responses to EGF were fully inhibited (additional file 10 and results not shown). This is in agreement with a previous study showing that LPA mitogenic signaling in MEFs does not require EGF receptor tyrosine phosphorylation [35]. Figure 10 illustrates that the transcriptional response to LPA was only little affected by EGF receptor inhibitor treatment (expression of 528 genes, reproducibly regulated by LPA at three different concentrations at $\mathrm{T}=4 \mathrm{hr}$ ). About $15 \%$ of the LPAinduced genes (81 out of 528 transcripts) was $>70 \%$ inhibited after drug treatment. Otherwise, EGF receptor inhibition did not affect the induction of key immediateearly and early genes by LPA, such as transcription factors and paracrine mediators. While it remains formally possible that basal EGF receptor activity has a permissive effect on some LPA-induced signaling events, we conclude that LPA and EGF signal independently to regulate broadly overlapping sets of genes in MEFs. It thus appears that the transcriptional program induced by either LPA-GPCR or EGF-RTK stimulation in fibroblasts is more strongly conserved than previously appreciated.

\section{Conclusion}

Dissecting the transcriptional response to growth factors in selected cell systems may help to better understand various aspects of embryonic development, adult tissue homeostasis and cancer. The present study characterizes the global transcriptional program of MEFs to LPA and thereby provides new insights into the normal physiological response of quiescent fibroblasts to this multifunctional lipid mediator. In addition to genes associated with cell proliferation, adhesion and migration, LPA induces a host of genes that encode secreted factors known to promote tissue remodeling, wound healing, inflammation, angiogenesis and tumor progression, depending on cellular context. This highlights the importance of LPA signaling in profoundly modifying the fibroblast microenvironment.

Previous transcriptional profiling of serum-stimulated human skin fibroblasts has identified a 'core serum response' (CSR) that is characterized by cell-cycle-inde- 

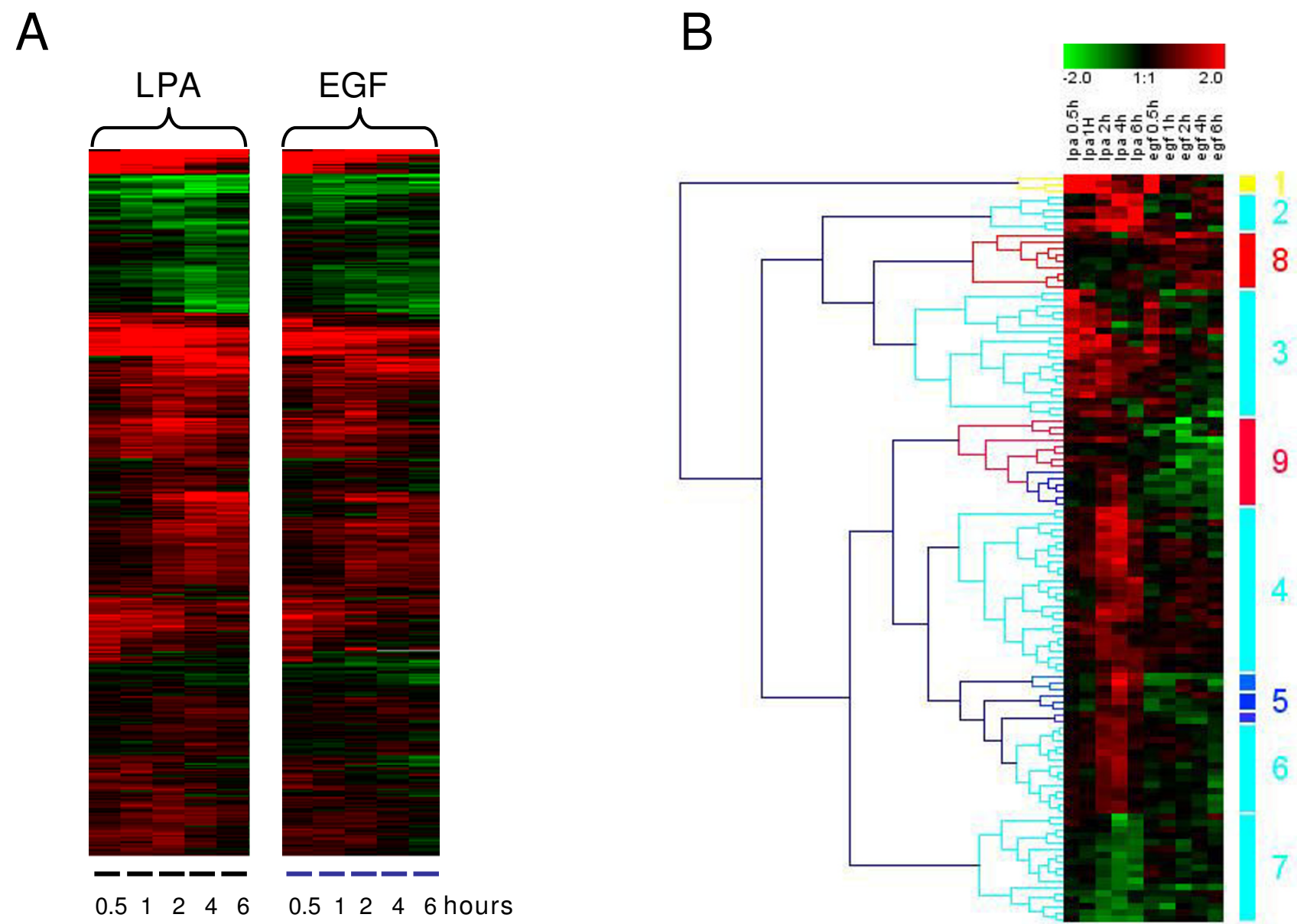

Figure 8

Differential expression patterns of LPA and EGF. (A) Global transcriptional responses to LPA (5 $\mu$ M) versus EGF (50 $\mathrm{ng} / \mathrm{ml}$ ) over time. Hierarchical clustering analysis was done on the 9/5-gene data set of Figure 5. (B) Heat map of I II reporters (encoding 105 genes) that are differentially regulated by LPA (cyan) and EGF (red), or inversely regulated by either agonist (blue). See also additional file 8: heat map of selected genes. Numbers (I-9) refer to additional file 9, which shows a list of all III reporters. Genes were identified by Anova analysis (two groups, $p<0.0$ I).

pendent genes and reflects various aspects of wound healing, notably the induction of genes involved in matrix remodeling and re-epithelialization [36]. This fibroblast CSR or "wound-response signature" is recapitulated in human carcinomas and may help predict tumor progression [37]. Comparative analysis revealed, however, that the expression profile of LPA-stimulated MEFs shows only limited overlap with the canonical CSR of serum-stimulated human fibroblasts. At first sight, this result is somewhat unexpected since LPA is a major serum constituent $[1,13]$. On the other hand, serum is an ill-defined mixture of numerous bioactive factors and it is likely that the combined action of many different factors obscures the comparison between serum and LPA. Moreover, MEFs differ from human skin fibroblasts not only in their biological and anatomic origin, but also in their LPA receptor expres- sion pattern (data not shown). Yet, it should be emphasized that LPA-stimulated MEFs and serum-stimulated human skin fibroblasts both show a gene expression profile that is strongly associated with tissue remodeling as well as tumor progression.

Of final note is our finding that the transcriptional response of MEFs to LPA versus EGF shows an overlap of $>90 \%$, at least qualitatively, despite the fact that LPA and EGF signal via completely different mechanisms. LPAinduced gene expression was largely independent of EGF receptor activity, which argues against the notion that LPA exploits the EGF receptor as a signaling intermediate. The broad overlap between LPA- and EGF-induced gene expression shows that GPCRs and RTKs have more in common than previously appreciated. One should not 

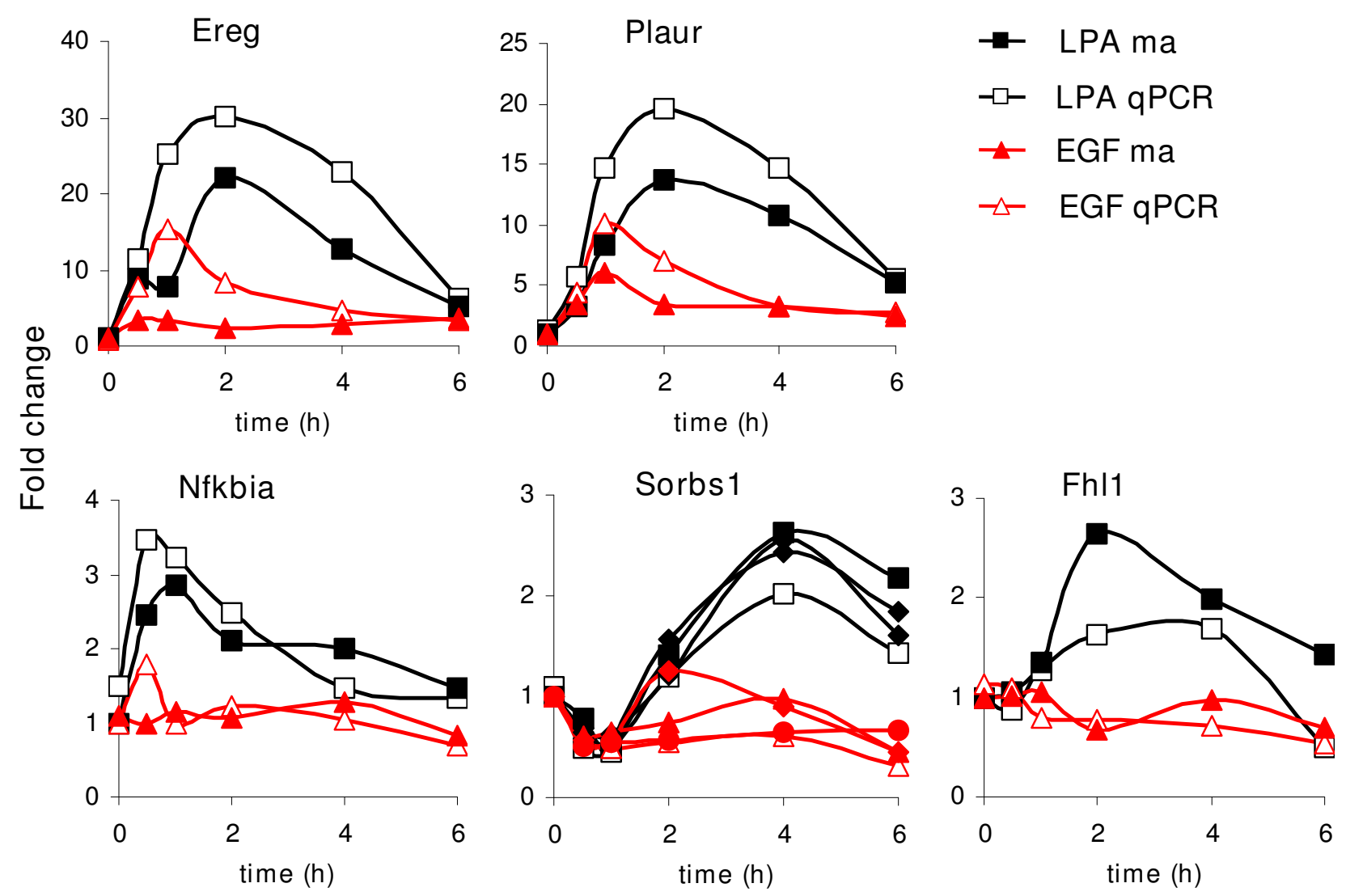

Figure 9

Differential regulation of selected genes by LPA (black) and EGF (red) validated by qPCR. qPCR data were normalized to HPRT mRNA concentration and plotted relative to the level at time zero. Data are presented as means \pm SD of duplicate experiments.

conclude, however, that the transcriptional response to receptor stimulation is less dependent on the nature of the receptor than on the cell type. For example, the common expression pattern of LPA and EGF shows hardly any overlap with that induced by Wnt signaling in fibroblasts [38]. The great diversity of fibroblast responses to LPA as reported here is an important area for further study.

\section{Methods}

\section{Cell culture}

Mouse embryonic fibroblasts (MEFs) were immortalized at passage 2 by retroviral introduction of the T-box member Tbx2 (LZRS-TBX2-ires-EGFP) to represses p53 function [39]. MEFs were cultured in Dulbecco's Modified Eagle's Medium (DMEM) supplemented with $8 \%$ fetal calf serum (FCS), penicillin and streptavidin, and seeded every three days at a density of $1.6 \times 10^{4} / \mathrm{cm}^{2}$ according to the $3 \mathrm{~T} 3$ protocol.

\section{RNA isolation and amplification}

Detailed protocols for RNA isolation, amplification, labeling and microarray hybridization can be found at http:// microarray.nki.nl/download/protocols.html. MEFs were seeded at density of $2.5 \times 10^{4} / \mathrm{cm}^{2}$, and $24 \mathrm{~h}$ later were starved for $40 \mathrm{~h}$ in serum-free medium supplemented with $0.2 \%$ bovine serum albumin (BSA; Sigma). Cells were treated with oleoyl LPA (0.3-5 uM) coupled to fatty acid free BSA (Sigma) at a 3:1 molar ratio, or EGF (20 ng/ $\mathrm{ml}$ ) for the indicated time period. Before harvesting, cells were washed twice with ice-cold phosphate buffered saline. Isolation of total RNA was performed with RNAzol Bee (Campro Scientific, Amersfoort, the Netherlands). Isolated total RNA was subsequently Dnase1-treated by using the Qiagen RNase-free DNase kit (Cat. no. 74106) and RNeasy spin columns (Qiagen, West Sussex, UK, Cat. no. 79254) and dissolved in RNase-free $\mathrm{H}_{2} \mathrm{O}$. RNA concentration and purity was measured on a NanoDrop ND- 


\section{EGF receptor inhibition}

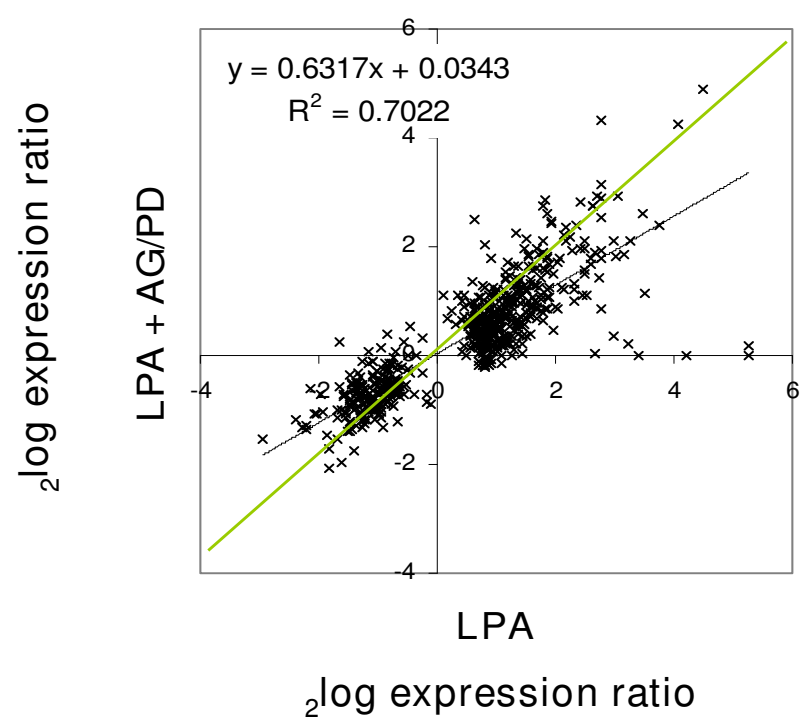

\section{Figure 10}

Correlation plot of the effect of EGF receptor inhibition. MEFs were treated with a mixture of two EGF receptor inhibitors (AGI478 and PDI68393, $250 \mathrm{nM}$ each) or DMSO (control) prior to stimulation with LPA $(5 \mu \mathrm{M})$ for 4 hrs. Microarray hybridization was performed using the corresponding time-zero control with the same pretreatment. The ${ }^{2}$ log expression level of 528 LPA-regulated genes after $4 \mathrm{hrs}$ is shown as a dot plot to correlate the effect of drug treatment on the expression level of individual genes. The expression level of 528 LPA-regulated genes in control cells was set at $100 \%$. The overall reduction of LPA-induced expression by the inhibitors was approx. $35 \%$, as inferred from the correlation coefficient.

1000 spectrophotometer (Isogen Life-Science), while RNA integrity was determined by agarose gel electrophoresis. Four micrograms of total RNA was used to synthesise cDNA with a T7-(dT)24 primer and RT superscript III (Invitrogen Life Technologies; Cat. no. L1016-01). After second-strand synthesis and removal of contaminating RNA, cRNA was generated by in vitro transcription using T7 RNA polymerase. Amplification yields were 1,000- to 2,000-fold.

\section{Microarray processing and data analysis}

The cRNA of each sample was labeled with Cy5 or Cy3 (Universal Linkage System, Kreatech Biotechnology, Cat. no. EA-006) according the manufacturer's protocol, with minor adjustments. For each labeling, $0.3 \mu \mathrm{l}$ of the Cy5ULS or $1 \mu \mathrm{l} \mathrm{Cy3-ULS} \mathrm{was} \mathrm{mixed} \mathrm{with} 1 \mu \mathrm{g}$ of cRNA and 2 $\mu \mathrm{l}$ of labeling solution. The volume of this mix was adjusted to $20 \mu \mathrm{l}$ and incubated for 30 minutes at $85^{\circ} \mathrm{C}$, followed by purification with a KREA pure column. Dye incorporation was determined after measuring the labeled cRNA on a NanoDrop ND-1000 spectrophotometer and mixed with the same amount of reverse color Cy-labeled cRNA from the untreated control. Labeled cRNAs were fragmented to pieces of 60-200 nt (Ambion, Cat. no. AM8740). Before hybridization, $20 \mu \mathrm{g}$ of COT-1 DNA (Invitrogen-Life Technologies, Cat. no. 15279-011), $8 \mu \mathrm{g}$ of yeast tRNA (Roche Diagnostics B.V., Cat. no. 10109495001) and $20 \mu \mathrm{g}$ of poly-d(A) (GE Healthcare Biosciences Europe GmbH, Cat. no. 27-7836-03) was added and the volume was adjusted to $60 \mu \mathrm{l}$. To this volume $60 \mu \mathrm{l}$ of a formamide buffer containing 50\% Formamide, 50\% $20 \times$ SSC ( NaCl/Na-citrate) and 0.1\% SDS was added. All hybridizations were performed in a hybridization station (Tecan, Cat. no. Hs4800). Before hybridization with the labeled RNA samples, the microarray was pre-hybridized with a bovine serum albumin solution ( $1 \%$ BSA, $5 \times$ SSC and $0.1 \%$ SDS) for one hour at $42^{\circ} \mathrm{C}$ and washed with water and a $5 \times$ SSC, $0,1 \%$ SDS solution. The labeled material was denatured at $95^{\circ} \mathrm{C}$ for 3 minutes and cooled to $42^{\circ} \mathrm{C}$ before injection in the hybridization chamber. After hybridization for $16 \mathrm{hrs}$, slides were washed in the hybridization station with a $5 \times$ SSC, $0,1 \%$ SDS solution, a $2 \times$ SSC, $0,1 \%$ SDS solution and a $1 \times$ SSC solution at $42^{\circ} \mathrm{C}$ and a $0,2 \times$ SSC solution at $23^{\circ} \mathrm{C}$. Finally, the slides were dried with medical grade nitrogen for $3 \mathrm{~min}$. at $30^{\circ} \mathrm{C}$. A DNA Microarray scanner (Agilent Technologies, Cat. no. G2505B) was used to scan the slides. To monitor the consistency of the array experiments, "self-self" experiments were performed using the same sample as reference. Fluorescent intensities of the images were quantified by using ImaGene v6.0 software (Biodiscovery Inc.). This software has an output of two text files which were uploaded to the CMF database (CMFdb, http://cmfdb.nki.nl) for further analysis. The background-corrected intensities from the Cy5 and Cy3 channel were used to calculate $\log _{2}$ transformed ratios. These ratios were normalized using a lowest fit per subarray [40]. Experiments done in dye-swap fashion were combined to create one dataset on which an outlier analysis was performed. A weighted average ratio and confidence level (P-value) was calculated per gene by a NKI platform adjusted error model [41], which was fine-tuned by self-self hybridizations. Differentially expressed genes between sample and reference were selected based on their P-value (a gene with a P-value $<0.01$ is considered an outlier). Genes were selected for further analysis if they had p-values $<0.01$ and $2 \log$ ratios greater than 0.67 or smaller than -0.67 corresponding to a 1.7 -fold change, unless indicated otherwise. To identify structural patterns of gene expression, selected outliers were used for hierarchical clustering using the complete linkage algorithm and for K-means clustering analysis (Euclidian distance) using the GENESIS program [42]. To identify genes that 
differ between LPA- and EGF induced treatment Anova analysis was applied (two groups) in which the expression values of two consecutive time points were used. "Ingenuity" pathway analysis was used for functional analysis on the set of significantly modulated genes to identify affected biological pathways and functional processes. In addition, the web-based platform Gene Ontology Tree Machine (GOTM) was used to identify GO terms with relatively enriched gene numbers [43].

\section{Microarray slides}

Mouse $32 \mathrm{k}$ Operon v3.0 oligo arrays from the Central Microarray Facility (CMF) at the Netherlands Cancer Institute were used for hybridization. A complete list of genes and controls present on the slides is available on the CMF web site http://microarrays.nki.nl/download/ geneid.html. The 70-mer oligo's (Operon, AROS v3.0) were printed on UltraGaps slides (Corning) with a BioRobotics MicroGrid II (Genomic Solutions) print robot. The description of our microarray study follows the MIAME guidelines and the entire microarray data set has been deposited in the EBI/ArrayExpress database and is accessible through accession numbers E-NCMF-16, E-NCMF-17, E-NCMF-18 and E-NCMF-19).

\section{Quantitative real-time RT-PCR}

Total RNA was extracted using the RNeasy minikit combined with on-column Dnase-I treatment (Qiagen, West Sussex, UK) and resolved in diethyl pyrocarbonate-treated $\mathrm{H}_{2} \mathrm{O}$ (DEPC; Sigma). First-strand cDNA synthesis was done using 2 ug of total RNA in presence of 0.5 ug oligodT primers (Invitrogen), 40 units RNase inhibitor Rnasin (Promega), 500 nM deoxynucelotide triphosphates (Roche), $10 \mathrm{uM}$ DTT and 10 units Superscript II RT in $1 \times$ reverse transcriptase buffer (Invitrogen). Sequences of real-time quantitative PCR primers were designed using Primer express software (PE Biosystems, Foster City, CA). Primer sequences are available upon request. Detection and quantification of each gene was accomplished by SYBRgreen incorporation using the ABI PRISM 7700 sequence detection system (Applied Biosystems). Quantitative RT-PCR was carried out using 40 ng cDNA, $300 \mathrm{nM}$ of each oligo in presence of $1 \times$ SYBRgreen mix in $20 \mathrm{ul}$ reactions (Applied Biosystems). Cycling parameters were: 2 min incubation at $50^{\circ} \mathrm{C}, 10 \mathrm{~min}$. incubation at $95^{\circ} \mathrm{C}$, followed by 50 PCR cycles consisting of $15 \mathrm{sec}$ at $95^{\circ} \mathrm{C}$ and $1 \mathrm{~min}$. at $60^{\circ} \mathrm{C}$. Product sizes were routinely verified by collecting a melting curve from $55^{\circ} \mathrm{C}$ to $95^{\circ} \mathrm{C}$ after final amplification. The relative product levels were quantified using the $2^{-\Delta \Delta \mathrm{CT}}$ method. Data are presented as relative induction of each target gene, normalized to the expression of HPRT, and are representative of two independent experiments.

\section{Authors' contributions}

CS performed the experiments, did the data and bioinformatics analysis and drafted parts of the manuscript. RK participated in the microarray experiments and helped with data analysis. WHM conceived and coordinated the study and wrote the manuscript. All authors read and approved the final manuscript.

\section{Additional material}

\section{Additional file 1}

Complete data set of LPA-regulated target genes in MEFs. 1508 genes were selected based on the criteria $p<0.01$ in at least two samples (i.e. two different time points or the same time point in independent doseresponse experiments; Figure 5), with a minimal fold-change of $>1.5$. Indicated are the ${ }^{2} \log$ ratios.

Click here for file

[http://www.biomedcentral.com/content/supplementary/14712164-9-387-S1.xls]

\section{Additional file 2}

Gene expression profiles clustered into different classes: immediateearly and early genes. See Figure 2 for details.

Click here for file

[http://www.biomedcentral.com/content/supplementary/14712164-9-387-S2.ppt]

\section{Additional file 3}

Gene expression profiles clustered into different classes: delayed and down-regulated genes. See Figure 2 for details.

Click here for file

[http://www.biomedcentral.com/content/supplementary/14712164-9-387-S3.ppt]

\section{Additional file 4}

List of selected genes that are most strongly regulated by LPA (5 $\mu \mathrm{M})$. Excel files showing 141 upregulated genes (Table 1) and 38 downregulated genes (Table 2).

Click here for file

[http://www.biomedcentral.com/content/supplementary/1471-

2164-9-387-S4.xls]

\section{Additional file 5}

Correlation plot of qPCR versus MA assays. Comparison of mRNA levels measured by microarray and qPCR assays. Each data point represents a single gene at a single time point $(Y=0.932 \times 1.24 ; R 2=0.8862, R=$ $0.941)$.

Click here for file

[http://www.biomedcentral.com/content/supplementary/1471-

2164-9-387-S5.ppt]

\section{Additional file 6}

Gene ontology analysis of the LPA-induced gene expression program in MEFs. Functional categories of genes showing peak expression at 2-4 hrs.

Click here for file

[http://www.biomedcentral.com/content/supplementary/14712164-9-387-S6.ppt] 


\section{Additional file 7}

Schematic representation of the LPA-induced expression program over time. Ingenuity pathway analysis. Red: upregulated genes. Green: downregulated genes.

Click here for file

[http://www.biomedcentral.com/content/supplementary/1471-

2164-9-387-S7.ppt]

\section{Additional file 8}

Heat map of selected genes that that are differentially regulated by LPA and EGF. Numbers of the clusters (1-4) refer to those in the heat map of Figure $8 B$ and the list of genes in additional file 9.

Click here for file

[http://www.biomedcentral.com/content/supplementary/14712164-9-387-S8.ppt]

\section{Additional file 9}

List of genes that are differentially regulated by LPA and EGF over time. Numbers of the clusters (1-9) refer those in Figure $8 B$. Genes were identified using Oneway Anova (two groups, $p<0.05$, using at least two time points).

Click here for file

[http://www.biomedcentral.com/content/supplementary/1471-

2164-9-387-S9.xls]

\section{Additional file 10}

Effect of AG1487 (250 $\mathrm{nM}$ ) on LPA- and EGF-induced cellular responses. Upper panel: MAP kinase activation ( $D E R K)$ as determined by Western blot; tubulin (tub) served as a loading control. Lower panel: Ccl2 mRNA expression after $1 \mathrm{hr}$ of agonist stimulation (qPCR determination).

Click here for file

[http://www.biomedcentral.com/content/supplementary/14712164-9-387-S10.ppt]

\section{Acknowledgements}

We thank Marloes Bagijn for PCR and biochemical experiments, Mike Heimerikx and Marja Nieuwland for assistance with the microarray studies, Arno Velds and Daoud Sie for bioinformatics assistance and Lodewijk Wessels for help with statistical analysis. We thank Panthea Taghavi for MEFs and the TBX2 vector. This study was supported by the Dutch Cancer Society and the Centre for Biomedical Genetics. The authors declare no conflict of interest.

\section{References}

I. Moolenaar WH, van Meeteren LA, Giepmans BN: The ins and outs of lysophosphatidic acid signaling. Bioessays 2004, 26:870-88 I.

2. Ishii I, Fukushima N, Ye X, Chun J: Lysophospholipid receptors: signaling and biology. Annu Rev Biochem 2004, 73:321-354.

3. van Meeteren LA, Moolenaar WH: Regulation and biological activities of the autotaxin-LPA axis. Prog Lipid Res 2007, 46:145-160.

4. Gardell SE, Dubin AE, Chun J: Emerging medicinal roles for lysophospholipid signaling. Trends Mol Med 2006, I 2:65-75.

5. Mills GB, Moolenaar WH: The emerging role of lysophosphatidic acid in cancer. Nat Rev Cancer 2003, 3:582-591.

6. van Meeteren LA, Ruurs P, Stortelers C, Bouwman P, van Rooijen MA, Pradere JP, Pettit TR, Wakelam MJ, Saulnier-Blache JS, Mummery $\mathrm{CL}$, Moolenaar WH, Jonkers J: Autotaxin, a secreted lysophospholipase $D$, is essential for blood vessel formation during development. Mol Cell Biol 2006, 26:50I5-5022.
7. Tanaka M, Okudaira S, Kishi Y, Ohkawa R, Iseki S, Ota M, Noji S, Yatomi $Y$, Aoki J, Arai $\mathrm{H}$ : Autotaxin stabilizes blood vessels and is required for embryonic vasculature by producing lysophosphatidic acid. I Biol Chem 2006, 28 I:25822-25830.

8. Nam SW, Clair T, Kim YS, McMarlin A, Schiffmann E, Liotta LA, Stracke ML: Autotaxin (NPP-2), a metastasis-enhancing motogen, is an angiogenic factor. Cancer Res 200I, 61:6938-6944.

9. Bhowmick NA, Neilson EG, Moses HL: Stromal fibroblasts in cancer initiation and progression. Nature 2004, 432:332-337.

10. Kalluri R, Zeisberg M: Fibroblasts in cancer. Nat Rev Cancer 2006, 6:392-40I.

II. van Corven EJ, Groenink A, Jalink K, Eichholtz T, Moolenaar WH: Lysophosphatidate-induced cell proliferation: identification and dissection of signaling pathways mediated by $\mathbf{G}$ proteins. Cell 1989, 59:45-54

12. Tager AM, LaCamera P, Shea BS, Campanella GS, Selman M, Zhao Z, Polosukhin V, Wain J, Karimi-Shah BA, Kim ND, Hart WK, Pardo A Blackwell TS, Xu Y, Chun J, Luster AD: The lysophosphatidic acid receptor LPAI links pulmonary fibrosis to lung injury by mediating fibroblast recruitment and vascular leak. Nat Med 2008, 14:45-54.

13. Eichholtz T, Jalink K, Fahrenfort I, Moolenaar WH: The bioactive phospholipid lysophosphatidic acid is released from activated platelets. Biochem J 1993, 29 I:677-680.

14. Gesty-Palmer D, El Shewy H, Kohout TA, Luttrell LM: beta-Arrestin 2 expression determines the transcriptional response to lysophosphatidic acid stimulation in murine embryo fibroblasts. J Biol Chem 2005, 280:32I57-32I67.

15. Symowicz J, Adley BP, Woo MM, Auersperg N, Hudson LG, Stack MS: Cyclooxygenase-2 functions as a downstream mediator of lysophosphatidic acid to promote aggressive behavior in ovarian carcinoma cells. Cancer Res 2005, 65:2234-2242.

16. Jeffrey KL, Camps M, Rommel C, Mackay CR: Targeting dual-specificity phosphatases: manipulating MAP kinase signalling and immune responses. Nat Rev Drug Discov 2007, 6:39 I-403.

17. Ferby I, Reschke M, Kudlacek O, Knyazev P, Pante G, Amann K, Sommergruber W, Kraut N, Ullrich A, Fassler R, Klein R: Mig6 is a negative regulator of EGF receptor-mediated skin morphogenesis and tumor formation. Nat Med 2006, I 2:568-573.

18. Zhang X, Pickin KA, Bose R, Jura N, Cole PA, Kuriyan J: Inhibition of the EGF receptor by binding of MIG6 to an activating kinase domain interface. Nature 2007, 450:74I-744.

19. Tavazoie SF, Alarcon C, Oskarsson T, Padua D, Wang Q, Bos PD Gerald WL, Massague J: Endogenous human microRNAs that suppress breast cancer metastasis. Nature 2008, 45 I: I47-I52.

20. Cobaleda C, Perez-Caro M, Vicente-Duenas C, Sanchez-Garcia I: Function of the zinc-finger transcription factor SNAI2 in cancer and development. Annu Rev Genet 2007, 41:41-6I.

21. Lake AC, Bialik A, Walsh K, Castellot JJ Jr.: CCN5 is a growth arrest-specific gene that regulates smooth muscle cell proliferation and motility. Am J Pathol 2003, 162:219-231.

22. Natarajan M, Stewart JE, Golemis EA, Pugacheva EN, Alexandropoulos $K$, Cox BD, Wang W, Grammer JR, Gladson CL: HEFI is a necessary and specific downstream effector of FAK that promotes the migration of glioblastoma cells. Oncogene 2006, 25: $172 \mid-1732$.

23. Kim M, Gans JD, Nogueira C, Wang A, Paik JH, Feng B, Brennan C, Hahn WC, Cordon-Cardo C, Wagner SN, Flotte TJ, Duncan LM, Granter SR, Chin L: Comparative oncogenomics identifies NEDD9 as a melanoma metastasis gene. Cell 2006, I 25: 1269-|28|.

24. Chan MW, El Sayegh TY, Arora PD, Laschinger CA Overall CM, Morrison C, McCulloch CA: Regulation of intercellular adhesion strength in fibroblasts. J Biol Chem 2004, 279:41 047-4I 057.

25. Fang X, Yu S, Bast RC, Liu S, Xu HJ, Hu SX, LaPushin R, Claret FX, Aggarwal BB, Lu Y, Mills GB: Mechanisms for lysophosphatidic acid-induced cytokine production in ovarian cancer cells. J Biol Chem 2004, 279:9653-966I.

26. Lee Z, Swaby RF, Liang Y, Yu S, Liu S, Lu KH, Bast RC Jr., Mills GB, Fang $X$ : Lysophosphatidic acid is a major regulator of growthregulated oncogene alpha in ovarian cancer. Cancer Res 2006, 66:2740-2748. 
27. Leask $A$, Abraham $D$ ]: All in the $\mathbf{C C N}$ family: essential matricellular signaling modulators emerge from the bunker. J Cell Sci 2006, I I 9:4803-48I0.

28. Hayakawa H, Hayakawa M, Kume A, Tominaga S: Soluble ST2 blocks interleukin-33 signaling in allergic airway inflammation. J Biol Chem 2007, 282:26369-26380.

29. Waters KM, Tan R, Genetos DC, Verma S, Yellowley CE, Karin NJ: DNA microarray analysis reveals a role for lysophosphatidic acid in the regulation of anti-inflammatory genes in MC3T3 EI cells. Bone 2007, 4I:833-84I.

30. Versteeg $\mathrm{HH}$, Ruf $\mathrm{W}$ : Emerging insights in tissue factordependent signaling events. Semin Thromb Hemost 2006, 32:24-32.

31. Gu J, lyer VR: PI3K signaling and miRNA expression during the response of quiescent human fibroblasts to distinct proliferative stimuli. Genome Biol 2006, 7:R42.

32. Pasternack SM, von Kugelgen I, Aboud KA, Lee YA, Ruschendorf F, Voss K, Hillmer AM, Molderings G], Franz T, Ramirez A, Nurnberg P, Nothen MM, Betz RC: $\mathbf{G}$ protein-coupled receptor $\mathbf{P} 2 \mathrm{Y} 5$ and its ligand LPA are involved in maintenance of human hair growth. Nat Genet 2008, 40:329-334.

33. Daub H, Weiss FU, Wallasch C, Ullrich A: Role of transactivation of the EGF receptor in signalling by G-protein-coupled receptors. Nature 1996, 379:557-560.

34. Schafer B, Gschwind A, Ullrich A: Multiple G-protein-coupled receptor signals converge on the EGF receptor to promote migration and invasion. Oncogene 2004, 23:991-999.

35. Andreev J, Galisteo ML, Kranenburg O, Logan SK, Chiu ES, Okigaki M, Cary LA, Moolenaar WH, Schlessinger J: Src and Pyk2 mediate G-protein-coupled receptor activation of the EGF receptor but are not required for coupling to the MAP kinase signaling cascade. J Biol Chem 200I, 276:20I30-20I35.

36. lyer VR, Eisen MB, Ross DT, Schuler G, Moore T, Lee JC, Trent JM, Staudt LM, Hudson J Jr., Boguski MS, Lashkari D, Shalon D, Botstein $D$, Brown PO: The transcriptional program in the response of human fibroblasts to serum. Science 1999, 283:83-87.

37. Chang HY, Sneddon JB, Alizadeh AA, Sood R, West RB, Montgomery K, Chi JT, van de Rijn M, Botstein D, Brown PO: Gene expression signature of fibroblast serum response predicts human cancer progression: similarities between tumors and wounds. PLOS Biol 2004, 2:E7.

38. Klapholz-Brown Z, Walmsley GG, Nusse YM, Nusse R, Brown PO: Transcriptional program induced by wnt protein in human fibroblasts suggests mechanisms for cell cooperativity in defining tissue microenvironments. PLOS ONE 2007, 2:e945.

39. Jacobs JJ, Keblusek P, Robanus-Maandag E, Kristel P, Lingbeek M, Nederlof PM, van Welsem T, van de Vijver MJ, Koh EY, Daley GQ, van Lohuizen M: Senescence bypass screen identifies TBX2, which represses Cdkn2a (pI9(ARF)) and is amplified in a subset of human breast cancers. Nat Genet 2000, 26:29I-299.

40. Yang YH, Dudoit S, Luu P, Lin DM, Peng V, Ngai J, Speed TP: Normalization for CDNA microarray data: a robust composite method addressing single and multiple slide systematic variation. Nucleic Acids Res 2002, 30:el5.

41. Hughes TR, Marton MJ, Jones AR, Roberts CJ, Stoughton R, Armour CD, Bennett HA, Coffey E, Dai H, He YD, Kidd MJ, King AM, Meyer MR, Slade D, Lum PY, Stepaniants SB, Shoemaker DD, Gachotte D, Chakraburtty K, Simon J, Bard M, Friend SH: Functional discovery via a compendium of expression profiles. Cell 2000, 102:109-126.

42. Sturn A, Quackenbush J, Trajanoski Z: Genesis: cluster analysis of microarray data. Bioinformatics 2002, 18:207-208.

43. Zhang B, Schmoyer D, Kirov S, Snoddy J: GOTree Machine (GOTM): a web-based platform for interpreting sets of interesting genes using Gene Ontology hierarchies. BMC Bioinformatics 2004, 5: 16.
Publish with Bio Med Central and every scientist can read your work free of charge

"BioMed Central will be the most significant development for disseminating the results of biomedical research in our lifetime. "

Sir Paul Nurse, Cancer Research UK

Your research papers will be:

- available free of charge to the entire biomedical community

- peer reviewed and published immediately upon acceptance

- cited in PubMed and archived on PubMed Central

- yours - you keep the copyright

Submit your manuscript here:

http://www.biomedcentral.com/info/publishing_adv.asp
BioMedcentral 